\title{
State Taxes in Guanajuato
}

\section{Impuestos Estatales en Guanajuato}

PAREDES-BARRÓN, Adriana $\dagger^{*}$, SILVA-CONTRERAS, Juan and ANDRADE-OSEGUERA, Miguel Angél

Universidad Tecnológica del Suroeste de Guanajuato

ID $1^{\text {st }}$ Author: Adriana, Paredes-Barrón / Researcher ID Thomson: S-6458-2018, arXiv Author ID: 73Y8LW-F8GQZB, CVU CONACYT ID: 947184

ID $1^{\text {st }}$ Coauthor: Juan, Silva-Contreras / ORC ID: 000-0003-1913-9910, arXiv Author ID: LAJ9UT-QHDDL4, CVU CONACYT ID: 509502

ID $2^{\text {nd }}$ Coauthor: Miguel Angél, Andrade-Oseguera / ORC ID: 0000-0002-7926-9162, Researcher ID Thomson: S-65862018, CVU CONACYT ID: 509502

\section{Abstract}

This article entitled State Taxes in Guanajuato briefly and precisely develops the taxes that are contributed in said state to comply in a timely manner, each tax includes the necessary elements to be understood and applied by the reader to their current tax situation such as who are the people who must comply with said tax, what will be applied and what percentage or rate should be applied to determine the amount to pay, in such a way as to help a healthy tax culture in our State and Country.

State taxes, Tax situation, Rate, Tax culture

\section{Resumen}

El presente artículo titulado Impuestos Estatales en Guanajuato desarrolla de manera breve y exacta los impuestos con los que se contribuye en dicho estado para cumplir en tiempo y forma, cada impuesto incluye los elementos necesarios para ser comprendidos y aplicados por el lector a su situación fiscal actual como quienes son las personas que deben cumplir con dicho impuesto, sobre qué se aplicará y qué porcentaje o tarifa se debe aplicar para determinar la cantidad a pagar, de tal manera que se ayude a una cultura tributaria sana en nuestro Estado y País.

Impuestos Estatales, Situación fiscal, Tarifa, Cultura tributaria

Citation: PAREDES-BARRÓN, Adriana, SILVA-CONTRERAS, Juan and ANDRADE-OSEGUERA, Miguel Angél. State Taxes in Guanajuato. Journal-Public Economy. 2020. 4-7: 1-8

$\dagger$ Researcher contributing as first author. 


\section{Introduction}

This article sets out in a general way the concept of taxes, elements that make them up for a better understanding considering that the majority of taxpayers in the State of Guanajuato fall into non-compliance with their obligations in tax matters due to bad or no information in said matter coupled with the difficulties that arise in such compliance. (newspaper el Correo, 2019) Said investigation will provide the citizens of the State of Guanajuato with the necessary information to understand and comply in a timely manner with the state taxes that are their responsibility.

\subsection{Justification}

This article will provide citizens of the State of Guanajuato with the necessary information to understand and comply in a timely manner with the state taxes that are their responsibility.

\subsection{Problem}

Most of the taxpayers in the State of Guanajuato fall into non-compliance with their obligations in tax matters due to the bad or no information in this matter, together with the difficulties that arise in such compliance. (newspaper el Correo, 2019)

\subsection{Hypothesis}

Taxpayers in the State of Guanajuato would comply with their tax obligations if they obtained clear and precise information on the procedure to carry it out.

\section{4 goals}

\subsubsection{General Objective}

Identify and Determine State Taxes in the State of Guanajuato based on the State revenue law.

\subsubsection{Specific objectives}

- Identify the subject, object, base, rate or rate and time in taxes for Guanajuato. (Guanajuato finance law, 2019)

- Determine the process for the generation of the payment or accreditation of said taxes. (Guanajuato finance law, 2019)

- $\quad$ Provide a basis for the taxpayer to fulfill their obligations. (Guanajuato finance law, 2019)

\section{Theoretical framework 2.1. Definition of Tax}

Taxes are a contribution (payment) in cash or in kind, of a mandatory nature, with which we cooperate to strengthen the country's economy. Taxes, in all economic systems of countries, serve to provide resources to the government so that it can achieve the objectives proposed in its planning. (Tax concepts)

\subsection{Destination}

Tax collection is intended to satisfy certain needs of a collective nature such as: public education, the administration of justice, security, public hospitals, infrastructure and public road services, programs and projects to support social development and economic, needs that each person could not pay for alone, but that, on the other hand, can be met with the contributions of all. These services incur costs and thanks to our contributions the Federation has the necessary resources to: have schools with teachers who contribute to your teaching; enjoy libraries, hospitals and sports centers; the maintenance of the streets of the city in which we live and their lighting; to build and fix roads; to have a fire service, police and military, who take care of maintaining our security. (Tax concepts).

\subsection{Elements of the Tax}

\section{Subject}

This can be of two types: active subject and taxable person. The active subject is the one who has the right to demand the payment of taxes. Thus in Mexico the active subjects are: the Federation, the states and the municipalities. The taxpayer is any natural or legal person who has the obligation to pay taxes in the terms established by law. However, it is necessary to note a difference between the taxpayer and the taxpayer, since many times confusion is generated, as happens for example with indirect taxes. The taxpayer is the one who has the legal obligation to pay the tax, while the taxpayer is the one who actually pays the tax.

\section{Purpose}

It is the activity or thing that the Law indicates as the reason for the tax, in such a way that it is considered as the generating event of the tax. 


\section{Base}

It is the taxable amount on which the tax amount is determined, for example: the amount of income received, number of liters produced, the annual income of a taxpayer, others.

\section{Share}

It is the amount of money that is received per tax unit, in such a way that it is set in absolute amounts. In case the amount of money received is as a percentage per unit then it is talking about the rate. (Taxes in Mexico)

\section{Principles governing Taxes Legality}

It refers to the fact that the contributions (taxes, rights, social security contributions and improvement contributions) must be established by the competent authority and in the Law, which establishes all the elements of the contribution.

\section{Proportionality}

The establishment of a contribution must attend to the existence of said wealth, since otherwise, the contribution is improper.

\section{Equity}

It is defined as equal treatment for the equals and unequal treatment for the unequal, that is, that all people who place themselves in the same legal assumption of causation must comply with their obligation to contribute and the same terms. (Principles of contributions)

\section{Tax Classification \\ Direct}

They are those that tax income, wealth, capital or equity and that directly affect the subject of the imposed, therefore it is not possible that the phenomenon of translation occurs. According to the repercussion criterion, the legislator intends to reach the true taxpayer by eliminating all types of intermediaries between the payer and the treasury. An example of direct taxes in Mexico is the Income Tax.
These taxes can be classified in turn as personal and real. The personal are those that take into account the conditions of the people who have the character of taxpayers. Real taxes are those that fall on the object of the tax, without taking into account the situation of the person who owns it. These are subdivided into taxes that are levied on the person considering them as an object and those that are levied on things.

\section{Indirect}

They are those that fall on production and consumption expenses, therefore their main characteristic is that they are transferable to the final consumer.

Among the main indirect taxes applied in Mexico are the Value Added Tax and the Special Tax on Production and Services. (Taxes in Mexico)

\section{Taxes in Mexico \\ Federal Taxes \\ Income Tax (ISR)}

This is a tribute that is applied to all people who have obtained income except donations and inheritances.

It is a direct tax because it directly taxes the sources of wealth. Income Tax is applied to legal and natural persons, as well as to foreign residents who have income from Mexico. The income tax rate varies between $1.9 \%$ and $30 \%$. (Taxes in Mexico)

\section{Value Added Tax (VAT)}

It is a type of indirect tax that taxpayers do not pay directly. This is collected through a third person, who ultimately reaches the end consumer. VAT is applied to most of the products you can buy. The VAT has different rates depending on what is bought or sold, these being $0 \%, 11 \%$ or $16 \%$. (Taxes in Mexico)

\section{Special Tax on Production and Services (IEPS)}

It is a tribute that is paid for the production and sale or importation of alcohol, gasoline, beer and tobacco. It is very similar to VAT, since in the end the tax is paid by consumers. 
Legal and physical persons are subject to this tax whenever they acquire any of the goods that we have defined in the previous paragraph. IEPS rates vary based on the percentage of alcohol in the beverage (from $26.5 \%$ to $53 \%$ ), while gasoline rates vary by state. (Taxes in Mexico)

\section{Business Flat Rate Tax (IETU).}

This is a tax that is applied and levied on legal and physical persons residing in the country. The main activities that are taxed in the tax are the sale of goods, the granting of the temporary use of goods and the provision of independent services. It is a tax that has a rate of $17.5 \%$. (Taxes in Mexico)

\section{Automobile Tax New (ISAN)}

It is a tribute that is in charge of establishing that vehicles that run on rechargeable electric batteries, electric vehicles that have an electric combustion engine or vehicles that run on hydrogen do not pay taxes. (Taxes in Mexico)

\section{State Taxes}

They are those that are applied within the borders of each state and that are not transferred to others. In other words, each state has a different tax rule in which the taxes charged are specified. (Guanajuato finance law, 2019)

\section{State Taxes in Guanajuato \\ Payroll Tax \\ Object}

This tax is subject to expenditures made in cash or in kind, for remuneration for subordinate personal work, regardless of the designation given to them, provided within the territory of the state; payments in money or in kind made to administrators, directors, commissioners or members of the directive, supervisory or administrative councils of any kind or type of companies or associations; and payments to individuals for fees, for the provision of independent personal services or for business activities, when they do not cause Value Added Tax because they are assimilated to salaries, in accordance with the Income Tax Law . For the purposes of this tax, the following are considered remunerations for subordinate personal work:
I. Payment of wages and salaries; II. Payments for overtime work; III. Payments of prizes, bonuses, bonuses, incentives, incentives and aid; IV. Compensation payments; V. Payments of bonuses and bonuses; SAW. Employer participation payments to the savings fund; VII. Seniority premium payments; VIII. Workers' profit sharing payments; IX. Commission payments; X. Payments in cash or in kind, directly or indirectly granted for the canteen and food services provided to the workers; XI. Pantry payments either in cash, kind or vouchers; XII. Transportation service payments, either directly or indirectly provided to workers; XIII. Insurance premium payments for medical or life expenses; XIV. Payments made to people for the services they provide to a borrower, provided that said services are carried out at the facilities or on behalf of the latter, for which the Value Added Tax is not payable; XV. Payments in goods and services, including the house, in addition to those in which the reservation of the right of your domain; and XVI. Any other indicated in this provision that is delivered in exchange for subordinate personal work, regardless of the name given to it.

\section{Subject}

Individuals and legal entities that make expenditures referred to in the previous article are subject to this tax, as well as economic units when the referred payments are made through them, when their domicile or that of their premises, establishments, agencies or branches , is located in the territory of the State or when the service is provided within it. The Federation, the State, the Municipalities, their parastatal and para-municipal entities, and the autonomous bodies, are obliged to pay this tax.

Individuals, legal entities and economic units that contract the provision of taxpayer services, whose domicile is located within or outside the territory of the State, are obliged to withhold and pay this tax, so that they make workers available, provided that the service personnel is provided in the territory of this Federal Entity.

In these cases, the obligated subjects must deliver the corresponding withholding certificate to the individual or legal entity or economic unit in question. 
They are jointly liable with the taxpayers of this tax, the individuals and legal entities that contract the provision of services, when the service providers do not comply with your obligation to pay the Tax About Payroll.

\section{Base}

The base of this tax is the amount of the expenditures made in money or in kind, for remuneration to subordinate personal work, regardless of the designation given to them, provided within the territory of the state; payments in money or in kind made to administrators, directors, commissioners or members of the directive, supervisory or administrative councils of any kind or type of companies or associations; and payments to individuals for fees, for the provision of independent personal services or for business activities, when they do not cause Value Added Tax because they are assimilated to salaries, in accordance with the Income Tax Law ; as well as expenditures when individuals or legal entities contract the provision of services from taxpayers domiciled in another Federal Entity, the performance of which generates the provision of subordinate personal work within the territory of the State, in terms of the provisions of articles 6 and 9 of this law.

\section{Rate}

This tax will be determined in accordance with the rate established annually by the Income Law. (Guanajuato finance law, 2019)

\section{Cedular Tax Subject and Object}

Individuals who, in the territory of the State of Guanajuato, obtain income in cash, goods, credit, services or any other type, for carrying out the following activities, are obliged to pay the scheduled taxes established in this Law: I For the provision of professional services; II. For the granting of the temporary use or enjoyment of real estate, located in the territory of the State; III. For carrying out business activities: a) General Regime; and b) Regime of Tax Incorporation; IV. For the sale of real estate. Individuals not resident in the State, who carry out the aforementioned activities, are also required to pay these taxes.

\section{Rate}

This tax will be determined in accordance with the rate established annually by the Income Law. (Guanajuato finance law, 2019)

\section{Incorporation Regime Fiscal Subject and Object}

Taxpayers who exclusively carry out business activities, who dispose of goods or provide services for which it is not required for their professional title, and whose income obtained in the immediately preceding fiscal year, would not have exceeded $\$ 2,000,000.00$, may apply the provisions of Section II, Chapter II, Title IV of the Income Tax Law, corresponding to the Tax Incorporation Regime, complying with the obligations of this schedule tax.

\section{Base}

The taxpayers referred to in the previous article, will calculate and pay the tax bimonthly, which will have the character of definitive payment, no later than the twenty-second day of the months of March, May, July, September, November and January of the next year. For these purposes, the fiscal profit of the two-month period in question will be determined by subtracting from the total income referred to in article 36 , obtained in said two-month period in cash, goods or services, the authorized deductions referred to in the Article 33 of this Law, which are strictly indispensable for obtaining the income referred to in this section, as well as the expenditures actually made in the same period for the acquisition of assets, expenses and deferred charges and the participation of workers in the profits of the companies paid in the exercise, in the terms of article 123 of the Political Constitution of the United Mexican States. To determine the tax, the taxpayers referred to in the previous article will consider the income when they are actually collected and will deduct the expenditures actually made in the year for the acquisition of fixed assets, expenses or deferred charges.

\section{Rate}

The tax profit obtained in accordance with article 36 of the Finance Law for the State of Guanajuato will be subject to the rate established annually by the Income Law. 
The tax to be determined may be reduced according to the percentages and according to the number of years they have

Taxing in the regime provided in Article 35. (Guanajuato Finance Law, 2019)

\section{Tax for Acquisition of Used Motor Vehicles Object}

The object of this tax is the acquisition of motor vehicles used by any title and that do not cause the value added tax.

\section{Subject}

Natural and legal persons who acquire the motor vehicles indicated in the previous article are obliged to pay this tax.

\section{Base}

The basis for the payment of this tax will be the highest price that results between the value of the operation and the one set by SATEG in the value tables that annually authorizes for this purpose, and that must be issued during the first quarter of the fiscal year., taking as reference the commercial purchase prices that govern between the merchants of the branch, or the one determined by SATEG itself through an appraisal.

\section{Rate}

This tax will be incurred and settled at the rate established annually by the Income Law, on the taxable base determined in accordance with the preceding article. (Guanajuato finance law, 2019)

\section{Tax on Lotteries, Raffles, Sweepstakes and Contests Object}

The object of this tax is the income obtained from prizes from lotteries, raffles, raffles and contests organized by the decentralized public bodies of the federal public administration, the purpose of which is to obtain resources to allocate them to public assistance. For the purposes of this tax, the refund corresponding to the ticket that allowed to participate in lotteries is not considered as a prize.

\section{Subject}

Individuals or legal entities that obtain income derived from prizes from lotteries, raffles, raffles and contests paid in the territory of the State are subject to this tax.

\section{Base and Rate}

This tax will be determined in accordance with the rate established annually by the Income Law for the State of Guanajuato, on the taxable base, consisting of the total amount of income obtained from the prizes corresponding to each ticket or whole ticket, without any deduction. (Guanajuato finance law, 2019)

\section{Taxes for lodging services Object}

The object of this tax is the payment for the provision of services of: I. Accommodation in:

a. Hotel establishments, hostels or motels; and

b. Apartments and houses, totally or partially.

II. Camps;

III. Mobile home stops; and

IV. Shared time.

The provision of accommodation services is understood to be the granting of shelter or accommodation in exchange for a consideration in money or in kind, whatever the name with which it is designated. For such purposes, the service is understood to be rendered, when it is carried out, within the territory of the State, regardless of the place or medium where the payment or consideration for said services is agreed or made.

\section{Subject}

They are obliged to pay this tax, the natural or legal persons that provide the services referred to in the previous article, who must transfer the amount to the people who receive the services subject to this tax. In case of non-compliance with the payment of this tax and when the consideration for hosting services is covered through a natural or legal person in its capacity as intermediary, promoter or facilitator, it will be jointly and severally liable for the payment of this tax. 


\section{Base}

The taxable base of this tax will be the total amount of the payment or the consideration received for the services rendered, object of this tax not including food, other related services and the Value Added Tax.

For the purposes of the preceding paragraph, the hosting service provider must itemize the corresponding tax in the voucher issued in accordance with the applicable tax legislation.

In the case of hosting services provided under the timeshare system or mode of use, the amount of the payments received in installments will be based on the tax, considering only the itemized amount of the hosting service.

\section{Rate}

This tax will be incurred and settled, applying to the taxable base referred to in the previous article, the rate established annually by the Income Law. (Guanajuato finance law, 2019)

\section{Vehicle Ownership or Use Tax.}

\section{Subject}

Individuals and legal entities who own or use private transport vehicles are obliged to pay the tax on the possession or use of vehicles, provided that the State issues the license plates to said vehicles. For the purposes of this tax, it is presumed that the owner, by whatever title, is the holder or user of the vehicle.

\section{Base}

All vehicles, including motorcycles, will have an exempt amount of $\$ 500,000.00$. When the total value of the vehicle is greater than the amount exempt, the tax caused will be the amount that results from reducing the exempt amount to said value and applying to the excess the corresponding rate established in the Income Law.

\section{Rate}

In the application of the rates established in the Revenue Law, the result will be the tax caused in the calendar year in which the vehicle is considered as new, as that corresponding to the model year, in the terms of sections I, VI and VIII of article 63 of this Law. In the years after the aforementioned, the tax caused in the year of calculation will be obtained by multiplying the amount obtained from the previous fractions by the factor indicated in the annual decrease table. (Guanajuato finance law, 2019)

\section{Tax on the final sale of alcoholic beverages}

\section{Object}

The purpose of this tax is to tax the final sale of alcoholic beverages in closed containers carried out in the territory of the State of Guanajuato, in establishments open to the general public with the exception of beer in all its presentations, mead and products of its fermentation. For the purposes of this tax, alcoholic beverages will be understood as those that at a temperature of fifteen degrees Celsius have an alcoholic strength of more than three degrees Gay Lussac up to fifty-five degrees Gay Lussac, including brandy and alcoholic beverage concentrates even when have a higher alcohol content, in accordance with the Special Tax on Production and Services Law.

\section{Subject}

Natural or legal persons who carry out the final sale of alcoholic beverages in closed containers carried out in the territory of the state of Guanajuato, in establishments open to the general public, except for beer in all its presentations, are required to pay the tax. mead and products of its fermentation.

\section{Base}

The base of this tax will be the price received for the final sale, reducing the Value Added and Special Tax on Production and Services. 


\section{Rate}

This tax will be incurred at the time the income is actually received and on the amount obtained from it and will be determined according to the rate established in the Income Law. (Guanajuato finance law, 2019)

\section{Conclusions}

According to experimental research carried out in Guanajuato, such as that exposed by C.P. Miguel Ángel Andrade Oseguera in his work entitled "Tax Culture in Guanajuato" it has been determined that the majority of taxpayers with business activity, specifically small and medium-sized companies, fail to comply with their tax obligations due to ignorance of the same or due to lack of support from the competent authorities, the bad image of the same that cause fear and mistrust or the expense involved in hiring a third party to carry out the calculation and payment of tax obligations. (Oseguera M. Á., 2012)

Therefore, the main objective of this research work is to provide the taxpayer of the State of Guanajuato with the necessary information to comply in a timely manner with their tax obligations.

Finally, this research is a tool for the disciplinary field in tax accounting by clearly exposing the elements necessary to enforce state taxes in Guanajuato.

\section{References}

Conceptos tributarios. (s.f.). Obtenido de www.sat.gob.mx

Impuestos en México. (s.f.). Obtenido de www.economia.unam.mx

INEGI. (2010). Obtenido de www.inegi.gob.mx

INEGI. (22 de 03 de 2017). Bhttp://www.inegi.org.mx/saladepr ensa/boletines/2016/especiales/es peciales2016_07_02.pdf.

(2019). ley de hacienda de Guanajuato. guanajuato.

Oseguera, M. Á. (25 de 05 de 2012). Cultura Tributaria para una mayor recaudación fiscal.
Cultura Tributaria para unamayor recaudació fiscal. Valle de Santiago, Guanajuato, Mexico: XVII Congreso Internacional de Contaduría, Administración e Informatica. periódico el correo. (28 de 08 de 2019). Obtenido de www.periodicoelcorreo.com.mx

Principios de las contribuciones. (s.f.). Obtenido de www.senado.gob.mx

SAT. (28 de 04 de 2015). http://www.sat.gob.mx/RegimenD eIncorporacionFiscal/quees.htm. Obtenido de http://www.sat.gob.mx/RegimenD eIncorporacionFiscal/quees.htm: http://www.sat.gob.mx/RegimenD eIncorporacionFiscal/quees.htm 